Supporting Information

\title{
Pure Water Solid Alkaline Water Electrolyzer Using Fully Aromatic and High-Molecular-Weight Poly(fluorene-alt-tetrafluorophenylene)-trimethyl Ammonium Anion Exchange Membranes and Ionomers
}

Roby Soni, ${ }^{\dagger}$ Shoji Miyanishi, ${ }^{\dagger}$ Hidenori Kuroki, ${ }^{\dagger \dagger}$ and Takeo Yamaguchi ${ }^{\dagger} *$

${ }^{+}$Laboratory for Chemistry and Life Science, Institute of Innovative Research, Tokyo Institute of Technology, 4259, Nagatsuta, Midori-ku, Yokohama 226-8503, Japan

* Kanagawa Institute of Industrial Science and Technology (KISTEC), R1-17, 4259, Nagatsuta, Midori-ku, Yokohama, Kanagawa, 226-8503, Japan

*Corresponding author: yamag@res.titech.ac.jp

\section{Experimental section}

(a) Materials: Iridium oxide $\left(\mathrm{IrO}_{2}\right)$ and $\mathrm{Pt} / \mathrm{C}(46.5 \mathrm{wt} \% \mathrm{Pt})$ were procured from Alfa Aeser and Tanaka Kikinzoku Kogyo K.K., respectively. As the gas diffusion layer (GDL) at the anode, we installed nickel foam purchased from MTI Corporation. Prior to use, the nickel foam was pressed to an approximate thickness of $200 \mu \mathrm{m}$ under $c a .9 \mathrm{MPa}$ for $10 \mathrm{~s}$. The GDL at the cathode was carbon paper (29AA, thickness $c a .190 \mu \mathrm{m})$ supplied by SGL Corporation. Dimethyl sulfoxide (DMSO), isopropanol, and methanol were purchased from FUJIFILM Wako Pure Chemical Corporation.

(b) Synthesis and properties of the PFOTFPh-TMA polymers: The synthesis and properties of PFOTFPh-TMA-Cx $(\mathrm{x}=6,8,10)$ are described in our previous publication (Ref 1). The polymer properties used in this study are shown in Table $\mathbf{S 1 .}$

(c) Preparation of anion exchange membranes (AEMs): To prepare the cast membranes of PFOTFPh-TMA polymers, $90 \mathrm{mg}$ polymer was dissolved in $3 \mathrm{~mL}$ DMSO with stirring at $150^{\circ} \mathrm{C}$ for $24 \mathrm{~h}$, obtaining a clear solution. This solution was poured into a flat $7 \mathrm{~cm}$-diameter petri dish. The DMSO was slowly evaporated by placing the petri dish on a hot plate held at $60{ }^{\circ} \mathrm{C}$. Once the DMSO had evaporated, the petri dish containing the membrane was transferred to a vacuum oven and dried for $1 \mathrm{~h}$ at $50{ }^{\circ} \mathrm{C}$ to evaporate the residual DMSO. 
Finally, the PFOTFPh-TMA polymer membrane was peeled from the petri dish and placed in deionized water for $30 \mathrm{~min}$, and subsequently dried at $60^{\circ} \mathrm{C}$ in a drying oven.

(d) Fabrication of membrane-electrode assembly (MEA) for solid alkaline water electrolysis (SAWE)

In this study, to demonstrate the applicability of PFOTFPh-TMA polymers to MEAs for $\mathrm{SAWE}$, commercial $\mathrm{IrO}_{2}$ and $\mathrm{Pt} / \mathrm{C}$ catalysts, which have been widely utilized as catalysts for water electrolysis, were employed. The MEA was fabricated by directly spraying the catalyst slurries on the membrane. During this process, the cathode was loaded with $\mathrm{Pt}$ at $0.3 \mathrm{mg} / \mathrm{cm}^{2}$ and the anode was deposited with $1.2 \mathrm{mg} / \mathrm{cm}^{2}$ of $\mathrm{IrO}_{2}$ catalyst. Here, the PFOTFPh-TMA-Cx polymer for ionomers was the same as that for the membrane polymer, namely, the PFOTFPh-TMA-C6, PFOTFPh-TMA-C8, and PFOTFPh-TMA-C10 ionomers were used for the MEAs using the PFOTFPh-TMAC6, PFOTFPh-TMA-C8, and PFOTFPh-TMA-C10 membranes, respectively.

(i) Preparation of $\mathrm{IrO}_{2}$ slurry: To prepare the $\mathrm{IrO}_{2}$ slurry, the PFOTFPh-TMA ionomer (25 $\mathrm{wt} \%$ in the catalyst layer) was dissolved in $5 \mathrm{~mL}$ of an isopropanol-water mixture (isopropanol:water volume ratio of 1:2.7 and 1:1 for PFOTFPh-TMA-C6 and PFOTFPhTMA-C8, respectively). Next, $40 \mathrm{mg}$ of $\mathrm{IrO}_{2}$ was added to the ionomer solution and the mixture was sonicated for $1 \mathrm{~h}$. The solvent used for the PFOTFPh-TMA-C10 polymer was a mixture of isopropanol, methanol, and water at a 4:8:5 volume ratio.

(ii) Preparation of $\mathbf{P t} / \mathbf{C}$ slurry: To prepare the $\mathrm{Pt} / \mathrm{C}$ slurry, $40 \mathrm{mg}$ of $\mathrm{Pt} / \mathrm{C}$ was mixed in $5 \mathrm{~mL}$ solvent containing the ionomer ( $25 \mathrm{wt} \%$ in the catalyst layer). The catalyst slurry was ballmilled with $\phi 5 \mathrm{~mm}$ zirconia balls at $150 \mathrm{rpm}$ for $1 \mathrm{~h}$ in a planetary ball mill (Pulverisette 6 , Fritsch).

(iii) Preparation of catalyst coated membrane (CCM): To obtain the catalyst-coated membrane $(\mathrm{CCM})$, the $\mathrm{Pt} / \mathrm{C}$ and $\mathrm{IrO}_{2}$ catalyst slurries were directly coated on the membranes of the cathode and anode catalyst layers, respectively, by a spray-coating technique (Nordson K.K.). Herein the PFOTFPh-TMA-Cx polymer for the ionomers was the same as that for the membrane polymer. The area of the electrode was $5 \mathrm{~cm}^{2}$. After spray coating, the CCM was 
dried overnight at $60{ }^{\circ} \mathrm{C}$ in a drying oven. The catalyst loadings and other CCM parameters are detailed in Table $\mathbf{S 2}$.

(iv) Water electrolysis cell fabrication: The CCM was sandwiched between the carbon paper (SGL 29AA) GDL at the cathode and the pressed nickel foam at the anode. The obtained MEA was set in a single electrolysis cell with single serpentine flow channels.

(e) Electrochemical measurements: First, the $\mathrm{Cl}^{-}$ions were replaced with $\mathrm{OH}^{-}$ions in the PFOTFPh-TMA ionomers and membrane by in-situ ion exchange in the MEA at $80{ }^{\circ} \mathrm{C}$ for 4 $\mathrm{h}$ while feeding $1 \mathrm{M} \mathrm{KOH}$ aqueous solution to the anode. Subsequently, the MEA was conditioned by applying a current density of $100 \mathrm{~mA} / \mathrm{cm}^{2}$ until the cell voltage remained constant. The resistance of the conditioned cell was measured at $80{ }^{\circ} \mathrm{C}$ by electrochemical impedance spectroscopy (EIS) at a DC voltage of $1.5 \mathrm{~V}$ with a DC amplitude of $10 \mathrm{mV}$. The EIS was performed by an electrochemical measurement system equipped with an impedance analyzer (HZ-7000, Hokuto Denko). The cell ohmic (IR) loss of the MEA was estimated from the measured cell resistance. The SAWE polarization curves were recorded at $80{ }^{\circ} \mathrm{C}$ and a flow rate of $5 \mathrm{~mL} / \mathrm{min}$ using an HJ1010SD8 charge-discharge unit (Hokuto Denko). The Tafel slopes were estimated from the Tafel plots (Figures S4 and S7) derived from the IR-corrected polarization curves (Figures $\mathbf{S 3}$ and S6) in the activation region at a low current density. The durability of the MEA for SAWE was tested at $80{ }^{\circ} \mathrm{C}$ at a constant current density of 200 $\mathrm{mA} / \mathrm{cm}^{2}$. During the measurements, $1 \mathrm{M} \mathrm{KOH}$ solution or water (preheated to $80{ }^{\circ} \mathrm{C}$ ) was fed to the anode at a flow rate of $5 \mathrm{~mL} / \mathrm{min}$.

(f) MEA fabrication for proton exchange membrane water electrolysis (PEMWE): For the performance comparison (Figure S2), we also prepared a PEMWE MEA with a Nafion 212 membrane (thickness $=50 \mu \mathrm{m}$ ). Similarly to the SAWE MEA fabrication, the $\mathrm{IrO}_{2}$ and $\mathrm{Pt} / \mathrm{C}$ catalysts were spray-coated onto the membrane. The $\mathrm{IrO}_{2}$ and $\mathrm{Pt}$ loadings were $1.2 \mathrm{mg} / \mathrm{cm}^{2}$ at the anode and $0.3 \mathrm{mg} / \mathrm{cm}^{2}$ at the cathode, respectively. The amount of ionomer (Nafion) in the catalyst layers was $25 \mathrm{wt} \%$. The electrochemical measurements were performed under the same protocols as the SAWE measurements. 


\section{Reference}

1. S. Miyanishi and T. Yamaguchi, Polym. Chem., 2020, 11, 3812-3820. 
Table S1. Properties of the PFOTFPh-TMA polymers (Ref 1).

\begin{tabular}{cccccc}
\hline Membrane & $\begin{array}{c}\text { Molecular } \\
\text { weight, } M_{\mathrm{w}} \\
(\mathrm{g} / \mathrm{mol})\end{array}$ & $\begin{array}{c}\text { IEC } \\
(\text { mequiv/g) }\end{array}$ & $\begin{array}{c}\mathrm{OH}^{-} \text {conductivity } \\
\text { at } 70^{\circ} \mathrm{C} \text { in water } \\
(\mathrm{mS} / \mathrm{cm})\end{array}$ & $\begin{array}{c}\text { Water } \\
\text { uptake at } \\
80{ }^{\circ} \mathrm{C}(\%)\end{array}$ & $\begin{array}{c}\text { Tensile strength } \\
\text { in air at } 23{ }^{\circ} \mathrm{C} \\
(\mathrm{MPa})\end{array}$ \\
\hline $\begin{array}{c}\text { PFOTFPh- } \\
\text { TMA-C6 }\end{array}$ & 178000 & 3.2 & 156 & 122 & 26.8 \\
$\begin{array}{c}\text { PFOTFPh- } \\
\text { TMA-C8 }\end{array}$ & 170000 & 2.9 & 117 & 74 & 28.5 \\
$\begin{array}{c}\text { PFOTFPh- } \\
\text { TMA-C10 }\end{array}$ & 240000 & 2.7 & 101 & 67 & 40.9 \\
\hline
\end{tabular}

Table S2. Characteristics of MEAs fabricated with various PFOTFPh-TMA polymers.

\begin{tabular}{cccccccc}
\hline MEA & $\begin{array}{c}\text { Membrane } \\
\text { and } \\
\text { ionomer } \\
\text { thickness } \\
(\mu \mathrm{m})\end{array}$ & $\begin{array}{c}\text { Membrane } \\
\text { Electrode }\end{array}$ & Catalyst & $\begin{array}{c}\text { Ionomer } \\
\text { in catalyst } \\
\text { layer } \\
(\mathrm{wt} \%)\end{array}$ & $\begin{array}{c}\mathrm{IrO}_{2} \\
\text { loading } \\
\left(\mathrm{mg} / \mathrm{cm}^{2}\right)\end{array}$ & $\begin{array}{c}\mathrm{Pt} \\
\text { loading } \\
\left(\mathrm{mg} / \mathrm{cm}^{2}\right)\end{array}$ \\
\hline $\begin{array}{c}\text { MEA- } \\
\text { C6 }\end{array}$ & $\begin{array}{c}\text { PFOTFPh- } \\
\text { TMA-C6 }\end{array}$ & 20 & Anode & $\mathrm{IrO}_{2}$ & 25 & 1.16 & - \\
$\begin{array}{c}\text { MEA- } \\
\text { C8 }\end{array}$ & $\begin{array}{c}\text { PFOTFPh- } \\
\text { TMA-C8 }\end{array}$ & $23(53)^{\mathrm{a}}$ & Anode & $\mathrm{IrO}_{2}$ & 25 & 1.22 & - \\
$\begin{array}{c}\text { MEA- } \\
\text { C10 }\end{array}$ & $\begin{array}{c}\text { PFOTFPh- } \\
\text { TMA-C10 }\end{array}$ & 34 & Anode & $\mathrm{Pt}^{2} / \mathrm{C}$ & 25 & - & 0.29 \\
\hline
\end{tabular}

a. The thickness of the MEA-C8 membrane was $23 \mu \mathrm{m}$ when acquiring the polarization curves and the durability data during water feeding, and $53 \mu \mathrm{m}$ when acquiring the durability data during $\mathrm{KOH}$ feeding (1 $\mathrm{M}$ in solution). 
Table S3. $\mathrm{H}_{2}$ permeabilities of the membranes.

\begin{tabular}{cc}
\hline Membrane & $\begin{array}{c}\mathrm{H}_{2} \text { permeability } \\
\text { at } 80^{\circ} \mathrm{C} \text { and } 90 \% \mathrm{RH} \\
\left(\mathrm{cm}^{3} \mathrm{~cm}^{2} \mathrm{~cm}^{2} \mathrm{~s} \mathrm{cmHg}\right)\end{array}$ \\
\hline Nafion 211 & $8.6 \times 10^{-9}$ \\
PFOTFPh-TMA-C6 & $1.1 \times 10^{-9}$ \\
PFOTFPh-TMA-C8 & $1.1 \times 10^{-9}$ \\
PFOTFPh-TMA-C10 & $4.7 \times 10^{-9}$ \\
\hline
\end{tabular}

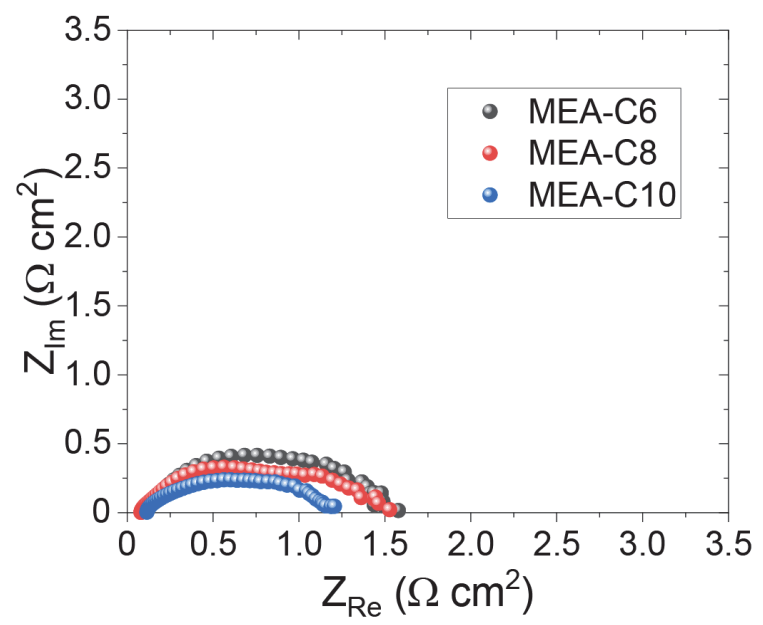

Figure S1. Nyquist plots recorded at $1.5 \mathrm{~V}$ and $80{ }^{\circ} \mathrm{C}$ for the MEAs fabricated with different PFOTFPh-TMA polymers and fed with a $1 \mathrm{M} \mathrm{KOH}$ solution to the anode. 


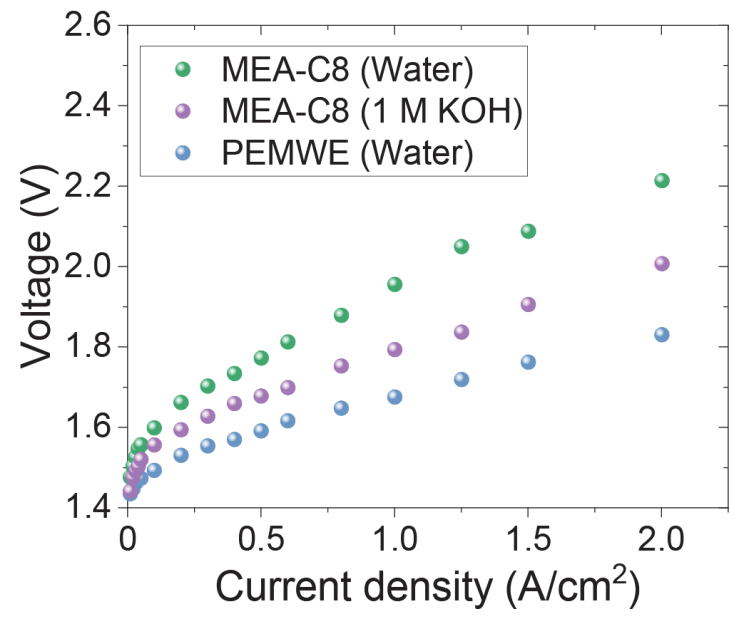

Figure S2. Performance comparison of solid alkaline water electrolysis using the PFOTFPhTMA-C8 membrane with water feeding and $1 \mathrm{M} \mathrm{KOH}$ feeding, and of proton exchange membrane water electrolysis (PEMWE) using a Nafion membrane.

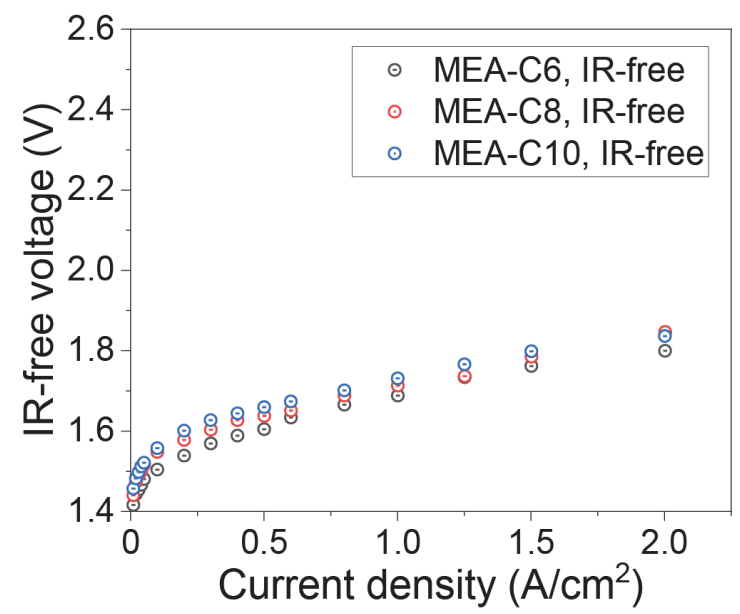

Figure S3. IR-free polarization curves of the MEA-C6, MEA-C8, and MEA-C10 membranes at $80{ }^{\circ} \mathrm{C}$ during feeding of $1 \mathrm{M} \mathrm{KOH}$ solution to the anode. 


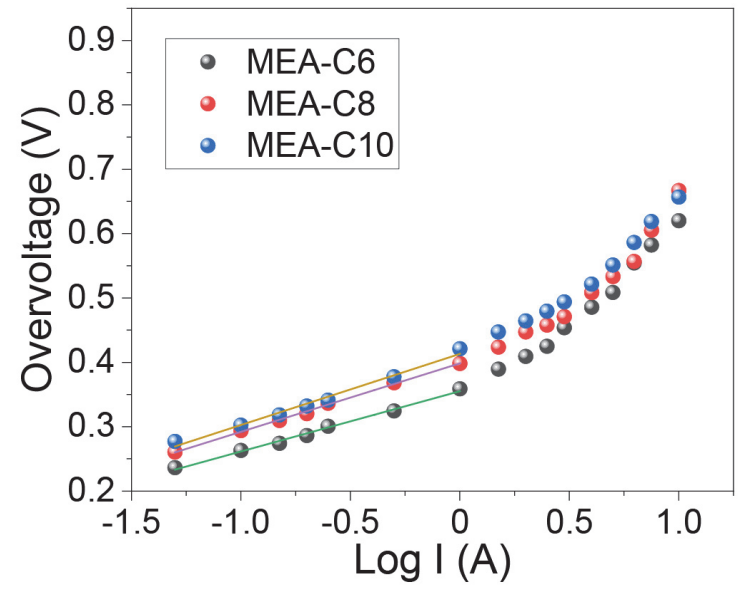

Figure S4. Tafel plots recorded at $80{ }^{\circ} \mathrm{C}$ for the MEAs fabricated with different PFOTFPh-TMA polymers and fed with a $1 \mathrm{M} \mathrm{KOH}$ solution to the anode.

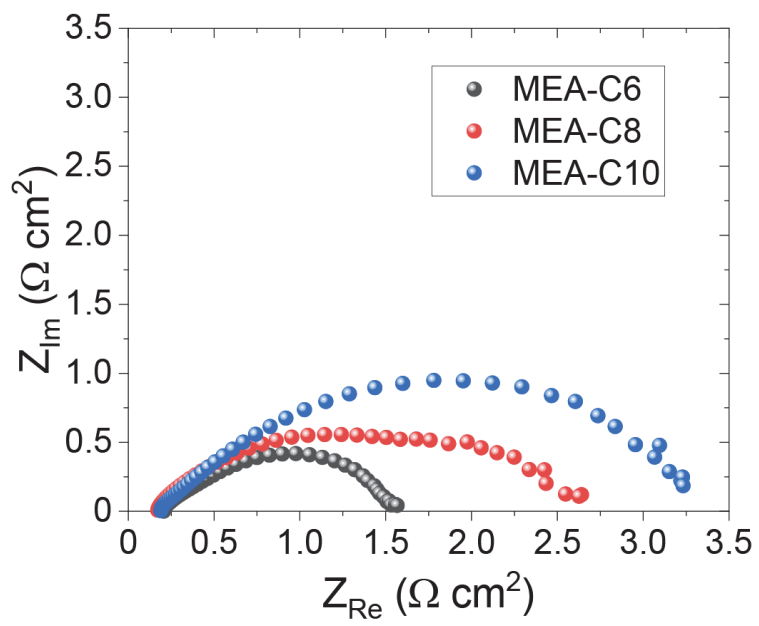

Figure S5. Nyquist plots recorded at $1.5 \mathrm{~V}$ and $80{ }^{\circ} \mathrm{C}$ for the MEAs fabricated with different PFOTFPh-TMA polymers and fed with pure water to the anode. 


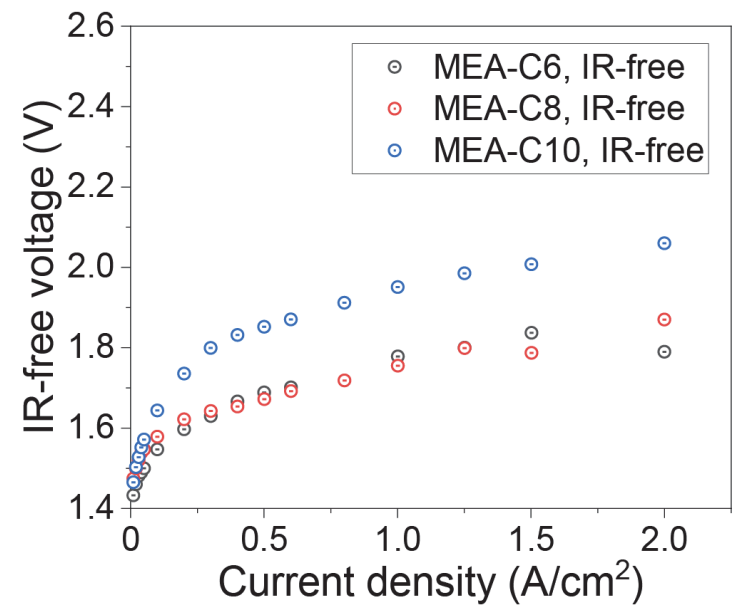

Figure S6. IR-free polarization curves of the MEA-C6, MEA-C8, and MEA-C10 membranes at $80{ }^{\circ} \mathrm{C}$ during feeding of pure water to the anode.

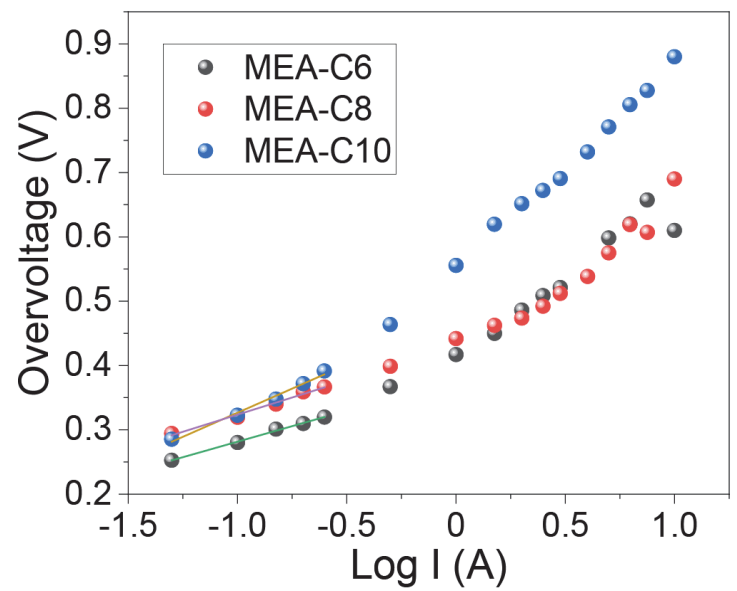

Figure S7. Tafel plots recorded at $80{ }^{\circ} \mathrm{C}$ for the MEAs fabricated with different PFOTFPh-TMA polymers and fed with pure water to the anode. 


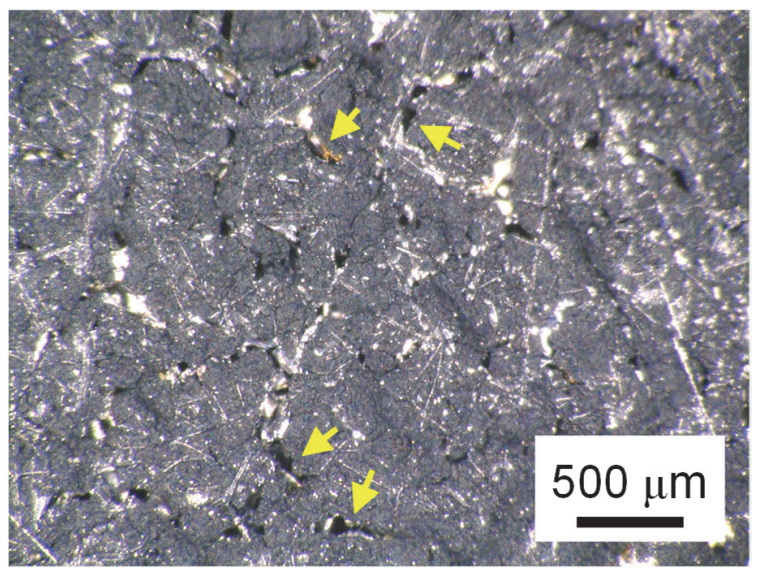

Figure S8. CCD image of the CCM on Ni foam for the MEA-C6 after durability testing using pure water feed at $80^{\circ} \mathrm{C}$. The yellow arrows indicate pinholes through which Ni foam could be seen. 